\title{
Multicentric Castleman disease
}

INSERM

\section{Source}

INSERM. (1999). Orphanet: an online rare disease and orphan drug data base.

Multicentric Castleman disease. ORPHA:93686

Multicentric castleman disease (MCD) is an aggressive form of Castleman disease (see this term) that mostly results from human herpesvirus 8 (HHV8) infection. It manifests by fever, diffuse lymphadenopathy, hepatosplenomegaly, Involvement of the respiratory system and increased C-reactive protein. 